\title{
Noncombatant Immunity and the Ethics of Blockade
}

\author{
Robert Mayer \\ Loyola University Chicago
}

Follow this and additional works at: https://ecommons.luc.edu/politicalscience_facpubs

Part of the Philosophy Commons, and the Political Science Commons

\section{Author Manuscript}

This is a pre-publication author manuscript of the final, published article.

\section{Recommended Citation}

Mayer, Robert. Noncombatant Immunity and the Ethics of Blockade. Journal of Military Ethics, 18, 1: 2-19, 2019. Retrieved from Loyola eCommons, Political Science: Faculty Publications and Other Works, http://dx.doi.org/10.1080/15027570.2019.1622257

This Article is brought to you for free and open access by the Faculty Publications and Other Works by Department at Loyola eCommons. It has been accepted for inclusion in Political Science: Faculty Publications and Other Works by an authorized administrator of Loyola eCommons. For more information, please contact ecommons@luc.edu. (c) (i) $\Theta$

This work is licensed under a Creative Commons Attribution-Noncommercial-No Derivative Works 3.0 License. (C) Taylor and Francis, 2019. 


\title{
Noncombatant Immunity and the Ethics of Blockade
}

\begin{abstract}
This paper counters Michael Walzer's argument against tight blockades. It shows that the interdiction of food shipments need not violate the principle of noncombatant immunity. Whether it is morally permissible to impose a strict blockade depends on the circumstances of the target state. The more self-sufficient a country is, the more acceptable it should be for a belligerent to cut the enemy's external lines of supply. The Allied blockade of Germany during the First World War illustrates the argument. Fault in this case should be assigned to the German government for the loss of civilian lives.
\end{abstract}

Key Words: naval blockade, starvation, noncombatant immunity, World War One, Germany, Michael Walzer

\author{
Robert Mayer \\ Political Science Department \\ Loyola University Chicago \\ 1032 North Sheridan Road \\ Chicago, IL 60660 \\ 773-508-3057 / rmayer@luc.edu
}

Biographical Note: The author received his doctorate from Princeton University in 1989. He is a Professor of Political Science at Loyola University. His published work has examined problems in distributive justice, democratic theory, and Russian radical thought. 


\section{Introduction}

Naval blockades employ sea power to produce effects far inland. They sever trade with a port or coast. In a strict blockade all maritime commerce is interdicted, including shipments of food. But without food people will starve. The most disadvantaged populations typically succumb first in a famine. A military measure that induces mass starvation, however, seems like an atrocity. It would appear to violate the central principle of jus in bello: noncombatant immunity. The civilian population is attacked when it is deprived of food. A blockade can be as deadly in its effects as the more ordinary forms of massacre. But massacres are always impermissible -- even when they are brought about without a shot being fired, as is sometimes the case with naval blockades.

Accounts of civilian hardship that result from food blockades are harrowing. An American journalist reporting from Germany during the First World War observed the effects of the Allied blockade in the sunken faces of a typical Berlin bread line:

In the case of the younger women and the children the skin was drawn hard to the bones and bloodless. Eyes had fallen deeper into the sockets. From the lips all color was gone, and the tufts of hair that fell over parchmented foreheads seemed dull and famished -- sign that the nervous vigor was departing with the physical strength (Schreiner 1918: 258).

Although civilians in this case did not expire in the street, the mortality rate among women and children increased by $50 \%$ due to malnutrition brought on by the blockade (Winter \& Robert 1997: 505). Experts later estimated that as many as three-quarters of a million civilians perished because their rations were too meager (Offer 1989: 34). That figure exceeds the total number of German civilians killed by the strategic bombing campaign during the Second World War. The 
Allied blockade that commenced in 1914 has been described as "the functional equivalent of an indiscriminate military attack on ordinary citizens, and so unjust war conduct” (Regan 1996: 95). Food should have been allowed to pass through the naval cordon, it has been argued. Blockades should never be this strict.

But in this paper I will explain why comprehensive blockades can sometimes be ethically acceptable. They need not violate the principle of noncombatant immunity. The Allied blockade of Germany during the First World War is a case in point. It was a defensible food blockade. The responsibility for the many civilian deaths that resulted, I will argue, should be assigned to the German government of that day. It made choices in response to the Allied blockade that eroded the health of vulnerable populations. Guns were produced at the expense of grain. Food was distributed inequitably. Civilian lives were thereby put at risk. The fault, I maintain, lies with the government that failed to provide for its own people when it would have been feasible to do so. Germany's enemies only forced its government to make difficult choices. The civilian deaths that resulted from the decisions the government made should be charged to its own account.

The argument I will develop in this paper about the ethics of blockade challenges the influential view set forth by Michael Walzer (2006: 160-175) in Just and Unjust Wars. Walzer likens the comprehensive blockade to the siege of a city filled with noncombatants and he argues that the blockading power must allow food to pass through its lines if it is to respect the immunity civilians should be accorded in the midst of hostilities. Because the Allies chose to cut off the overseas transport of food into Germany during the First World War, Walzer assigns responsibility for the civilian deaths that followed to them and not to the German government. But I will explain how the opposite judgment can be reached from within the paradigm of just- 
war theory. The argument I develop accepts the principle of noncombatant immunity but clarifies from what it is that noncombatants are to be rendered immune. The defense I offer for food blockades like the one imposed by the Allies during the First World War does not appeal to the argument from supreme emergency or to the excuse of military necessity. It also follows Walzer in according moral equality to soldiers and to civilians, regardless of whether the causes for which their governments lead them into war are just or unjust. The argument about the propriety of strict blockades does not turn on these matters. It turns, instead, on whether we think it is reasonable to expect belligerent powers to prioritize the lives of their own noncombatants and to accept a loss of fighting force in order to spare the innocent more hardship in war. If those expectations are reasonable, I argue, then the food blockade can be a legitimate military measure.

\section{The Conventions of Blockade}

While any effort to cut off access to a particular location could be described as a blockade, the term has a more precise meaning in international law (Oppenheim 1952: §370). A naval blockade in this stricter sense operates in or near the territorial waters of an enemy and interdicts all maritime traffic. Neither belligerent nor neutral vessels are permitted to pass through the cordon, regardless of cargo. An authentic blockade seeks to inhibit shipping along a stretch of enemy territory as thoroughly as does the investment of a city by land. Blockades in this technical sense, then, are always total, tight, and close (Frostad 2018).

Naval interdiction, however, may take other forms than the strict blockade. When it ranges far from the enemy's coasts, the interdiction is necessarily more discriminating than a close blockade, which seizes neutral and enemy transports alike within its zone of operation. On the high seas, enemy merchant vessels may still be captured at will, no matter the cargo or 
destination (Green 2008: 196). They are the legitimate spoils of war, even when they carry food bound for the civilian population. This is because the ships are enemy possessions. Just as the enemy food train may be captured by land forces everywhere except in neutral territory, so may a belligerent food transport be intercepted anywhere outside neutral waters. In both cases enemy noncombatants are not to be attacked unless they offer resistance, but all of the goods they convey (as well as the conveyances themselves) may be seized without compensation. With regard to enemy vessels, then, the rules of capture are identical, whether those ships are seized near a blockaded port or far out to sea. They and their cargoes are always liable to be confiscated, precisely because they belong to the enemy. ${ }^{1}$

Neutral transports, however, are to be treated with more circumspection on the high seas than when they are caught trying to run a close blockade (Bell 1937: 2-3). In the latter case, the neutral ship loses the immunity that neutrality bestows because it seeks to aid one side in the conflict at the expense of the other. But out at sea obstruction of neutral commerce might well be taken for a hostile act. If the seas are free, neutral shipping should pass unmolested. But if these ostensibly neutral transports are ferrying military supplies to the enemy, then they do not seem to be neutral in fact. International law therefore permits belligerents to confiscate contraband of war on the high seas when it is being conveyed to the enemy aboard neutral vessels (Oppenheim 1952: §404). Neutral transports may be stopped and searched for this purpose, but this more distant and more discriminating form of interdiction is not classified as blockade in the proper sense (Gordon \& Dangerfield 1947: 18-19).

How broadly the category of contraband may be construed has always been a disputed issue. Weapons and ammunition certainly qualify, but belligerent powers have often claimed a right to seize other goods -- including food -- that contribute to the enemy's war effort (Hall 
1924: 787-89). Some naval powers have also claimed a right to take as prize goods being conveyed to a neutral port if the ultimate destination of the contraband can be shown to be the enemy. This is known as the doctrine of continuous voyage. When neutral states are strong these more expansive policies of interdiction are contested as unwarranted interference with neutral commerce and might be taken as a provocation to war. How discriminating belligerent interdiction is at any given time on the high seas with regard both to the contents and to the destination of neutral cargoes is a metric of the relative power of neutral and belligerent states. Belligerent powers claim the right to prevent third parties from aiding the war effort of their enemies; neutral powers claim the right for their citizens to trade with whomever they please. The authorities on the law of nations seem to agree that whatever rules operate during any given war with regard to the scope of interdiction at sea depends more on the relative strength of the contending parties than on unambiguous and widely shared moral principles (Green 2008: 199).

As a beginning point, then, we should recognize that the rules of naval warfare as they operated before 1914 permitted any belligerent to impose a food blockade along its enemy’s coasts if that belligerent power had the naval forces to do so. The various conventions negotiated between the great powers before the First World War specified that a close blockade had to be made known through a formal declaration so that neutral ships could steer clear of the war zone and avoid confiscation (Oppenheim 1952: §368). The rules also stated that the blockader could not let some neutral ships pass through the cordon if any were turned away because this would bestow an unfair trading advantage. Further out to sea, there was a wide consensus that food shipments could also be seized as spoils of war when carried in enemy transports. There was deep disagreement, however, about the propriety of seizing food cargoes destined for enemy territory when they were conveyed in neutral bottoms. States disagreed about whether these 
shipments qualified as contraband of war, especially when the food was being transported from one neutral port to another and would only later be conveyed into enemy hands across a neutral border. The objection in this case, though, was not that enemy civilians might starve if the food was seized but that neutral sovereignty and neutral property rights were being infringed. Starvation was accepted at this time as a harsh yet permissible method of prosecuting a war (Chambers 1939: 139). The traditional rules of naval interdiction were formulated, we should be clear, not to prevent starvation of noncombatants but to regularize relations between belligerents and neutrals. The aim was to reduce the possibility that their interactions at sea would broaden existing conflicts. The belligerent was trying to win a war; the neutral was trying to protect a profit opportunity. The rules they negotiated were concerned to secure these rights and not the right of hungry people to be fed.

Since 1914, the law of war has evolved considerably. According to Article 54 of the 1977 Protocol to the Geneva Convention, "Starvation of civilians as a method of warfare is prohibited." Tight land sieges are now therefore illegal. However, the official commentary states that "the prohibition is not intended to alter the rules on naval blockade" (De Lupis 1987: 253). Those rules have not been amended in more than a century. But a stricter norm regarding naval blockades does seem to be evolving. The nonbinding yet authoritative San Remo Manual on International Law Applicable to Armed Conflicts at Sea prohibits naval blockades for "the sole purpose of starving the civilian population." What is more, in cases where "the civilian population of the blockaded territory is inadequately provided with food and other objects essential for its survival, the blockading party must provide for free passage of such foodstuffs and other essential supplies" (Doswald-Beck 1995: 27). This would seem to rule out blockades like the one the Allies erected during the First World War. However, the manual goes on to state 
that relief shipments may be barred by the blockading force when "a definite military advantage would accrue to the enemy by their substitution for enemy goods that would thereby become available for military purposes" (37). This latter qualification is crucial. As I will show, it fits the German case exactly. Hence, even if the new norm is applied retroactively to this historical case, the Allied blockade should not be faulted. Its sole purpose was not to starve the civilian population.

In later sections of the paper we will be concerned with the problem of what the rules of naval interdiction should be as opposed to what the law of war says they are. But we should note at the outset that every blockade in the strict sense has always been a food blockade. Goods of every sort are interdicted by the blockading force (Jessup 1928: 23). Commerce is severed with the enemy coast. What I want to show in subsequent sections of this paper is that this constrictive method of warfare is sometimes morally permissible -- even when the deliberate starvation of noncombatants is proscribed, as I agree it ought to be.

\section{The Surrogate Blockade}

The system of naval interdiction established by Great Britain at the start of the First World War was neither total and tight, nor close. It did not claim to be a blockade in the technical sense (Coogan 1981: 156). The German coasts were never cordoned off by a picket of military vessels. But over time the interdiction of seaborne commerce bound for Germany became increasingly tight and total. The novel system devised by the British and introduced incrementally was perfected after the United States entered the war in 1917. In its effects the Allied interdiction came to approximate a close blockade while dispensing with the legal formalities. It was a blockade by other means (Guichard 1930: 43). 
It was not feasible for the Allies to establish a legal blockade of the German coasts in 1914 or later because naval operations along the shoreline were too dangerous even for the world's mightiest fleet. Surface vessels patrolling in or near Germany's territorial waters would have had to evade not only concentrations of enemy warships but also long-range artillery, fixed and floating mines, submarines, fast-moving torpedo boats, and air attack. Throughout the war the British fleet never dared to sail into the Baltic Sea and thus could not establish a close blockade along much of Germany's coastline. But over time the British and their allies devised a way to cut off most of their enemy's overseas trade by progressively tightening the system of long-range naval interdiction. Pressure was exerted in new ways on neutral shipping to constrict the flow of supplies into Germany. Foreign traders were compelled to behave as if a close blockade had been imposed, even though such an operation wasn't militarily feasible (Bell 1937: 234).

The process of constriction began in the first month of the war, when the British government informed neutral shippers that it was extending considerably the list of contraband goods it would confiscate to hinder the enemy war effort (Jessup 1928: 36-37). These goods were to be seized as prize even when consigned to a neutral port if the ultimate recipient was thought to be the German government. Food shipments intended for civilian consumption, however, were not yet prohibited (Bell 1937: 51, 59, 115). After a few months it was announced that all neutral merchantmen sailing past Great Britain would be required to call at designated ports or staging areas for inspection (Osborne 2004: 68). Vast minefields were laid in open waters to channel shipping toward these inspection points. Soon thereafter the British government began to negotiate arrangements with neutrals in northern Europe (Denmark, Norway, Sweden, and the Netherlands) that prevented the supplies coming into their ports from 
being transferred to Germany by land or sea. Later, quotas would be established to ensure that only enough supplies flowed in to satisfy the neutral country's domestic needs. Firms registered in these neutral countries that were known to trade with the enemy were blacklisted and any shipments consigned to them were seized before arrival (Bell 1937: Part II).

As this system of interdiction tightened, the German government retaliated by designating the waters around the British Isles as a war zone in which merchant shipping could be sunk on sight. Such a policy brazenly flouted the principle of noncombatant immunity, which the new British methods of interdiction continued to respect. Neutral vessels were never attacked by the Allies, but their cargoes could be confiscated by a Prize Court and their freedom to ply the seas and to trade with whomever they pleased was sharply constrained (Hampshire 1980). The surrogate blockade infringed rights that neutral traders had traditionally been accorded by belligerent powers and therefore elicited vigorous protest (Coogan 1981). But the Allies did no more than international law would have permitted if Germany had been an island nation and its approaches could be blockaded (Siney 1957: 246). Neutral parties were pressured to behave as if Europe's mightiest land power had been surrounded on all sides by hostile forces that would not permit supplies to pass through. Such a cordon could not be established in practice, but none of the neutral powers was willing to go to war with Britain for the sake of a right to trade freely with its enemies that was infringed without the loss of neutral lives and that would have lapsed in any case if Germany had been surrounded militarily. By contrast, a neutral power (the United States) did declare war on Germany after it tried to establish an ersatz blockade of its own but through the much blunter method of sinking neutral shipping without warning. This violated both the letter and the spirit of blockade law, a central purpose of which had always been to spare the lives of noncombatants at sea. The new rules of blockade imposed by the British still adhered 
scrupulously to this purpose even as they exerted pressure on neutral shippers to behave as if Germany was more cut off from them as a destination than was actually the case.

Until Germany's U-Boat blockade drove the United States into the war, the new Allied system of interdiction was quite porous (Consett 1923). Neutral trade with Germany swelled during the first years of the conflict because its own considerable merchant fleet was rapidly driven from the seas by the threat of capture. The British released many neutral ships from their inspection points if promise was given that the cargoes would not be exported to Germany, but these coerced promises were often broken (Osborne 2004: 85, 91). Only later were shipments of food rationed so as not to exceed the needs of the neutral population. While the United States remained out of the war, Britain had to be cautious about infringing the traditional rights of neutral states. But when the world's foremost economic power joined the Allied cause, the virtual blockade was soon tightened. American businesses were no longer permitted to earn profits by supplying Germany's needs.

Those needs increasingly went unmet as the war continued. Deprivation swelled in the urban population of Germany. The average city-dweller had shed $20 \%$ of her body weight by the war's end (Offer 1989: 33). Bread was rationed first but eventually all food consumption was regulated by the state. In the last phases of the war the ration coupons afforded their recipients no more than about 1000 calories a day, or less than half the needs of the average adult (Vincent 1985: 49). Hundreds of thousands of civilians succumbed to illnesses brought on by chronic malnutrition. Many of the people standing in bread lines were so emaciated that they were said to smell like rotting corpses (Schreiner 1918: 248).

That there is a causal connection between the blockade the Allies erected and the loss of civilian lives Germany suffered cannot be doubted. But in later sections of the paper I will 
examine more carefully that causal process and explain why responsibility for these deaths could plausibly be assigned to the victims' government rather than to their enemies. Before I do that, however, I will explain why just-war theorists in recent decades have come to reject food blockades like the one the Allies imposed on Germany during the First World War. ${ }^{2}$

\section{The Analogical Objection}

Michael Walzer's influential criticism of the food blockade is made in the chapter of Just and Unjust Wars entitled "War against Civilians." He likens the naval blockade of a coastline to the siege of a city from which noncombatants are not permitted to flee. The loss of civilian life that follows is compared to an armed attack that fires through a crowd of civilians trapped on the field of battle. These analogies give the argument its force. They construe the strict blockade as a willful or reckless massacre. This method of weakening an enemy is therefore said to violate the central prohibition of the war convention: the principle of noncombatant immunity.

Walzer (2006: 160-70) criticizes siege operations that lock noncombatants into a fortified position and do not permit them to flee the fight. Whichever belligerent hinders the exit of noncombatants is made responsible for the deaths that follow due to bombardment or starvation. To the besieger who blocks the way out Walzer ascribes the intention of deliberately slaughtering innocents as a way to compel the garrison's capitulation: "The goal is surrender; the means is not the defeat of the enemy army, but the fearful spectacle of the civilian dead" (161). The doctrine of double effect cannot exonerate the besieging army in this case, Walzer points out, because the civilian deaths are not merely foreseen but are deliberately intended (162). It is like torturing hostages to death in plain view in order to force the enemy to surrender. This method of struggle shatters the war convention as deliberately as does the indiscriminate 
bombardment of residential neighborhoods. Both forms of military operation murder noncombatants randomly and could therefore be classified as forms of (state) terrorism. Walzer argues persuasively that siege operations are only permissible after the belligerents have permitted noncombatants to escape from the scene of battle. If they are given the chance to go but choose to stay, the civilian deaths that follow are no longer the fault of the besieging force (168-69). Unarmed people may still succumb to starvation because the enemy will not permit food to pass through its lines, but this embargo is no longer the proximate cause of those deaths. Rather, it was the decision to stay when flight was feasible that killed these noncombatants. We cannot say, as we could in the other case, that it was the besieger who massacred them. The civilian deaths are now the unintentional result of the siege operation that nonetheless deliberately cuts off the flow of food into the city.

The siege is to the city what the blockade is to the nation. Both interdict supplies, but Walzer argues that blockades may never be as strict as sieges are permitted to become because it is unreasonable to expect civilians to evacuate their homeland as we might expect them to evacuate a city that is soon to be surrounded (170-75). Exit isn't a morally feasible option. The populace is trapped by its own borders. Hence it cannot consent to the naval blockade as the inhabitants of a city might consent to a siege. The populace has no way to escape the fight, which is now strategic rather than tactical. This is why Walzer repudiates the food blockade as a military measure. It does not give civilians a way out. They will starve first because soldiers are fed before civilians. The method therefore only weakens the enemy's fighting force indirectly. The soldiers still eat, but the people for whom they fight waste away. Their gradual emaciation is meant to pressure those who bear arms into capitulating. Surrender is being extorted from them as the only alternative to mass starvation. Civilians are thereby transformed into hostages. But 
the principle of noncombatant immunity surely rules out this sort of operation. It prohibits belligerents from making war on civilians as a way to win. It isn't permissible to starve a country into submission.

The food blockade erected by the Allies during the First World War should therefore have been unacceptable, Walzer concludes. Victory has to be won on the field of battle. Civilians cannot be attacked in the rear. Just wars are fought in such a way that noncombatants are less likely to be harmed than combatants (151-59). Soldiers must expose themselves to the greater risks. But that doesn't happen when the blockader cuts off food deliveries from a distance and then waits for the resulting civilian misery to break the will of the enemy. This method of fighting is not very different from executing hostages one by one until the enemy surrenders. The one is as much an atrocity as the other.

If blockades are like sieges, and if sieges are like massacres, then Walzer's repudiation of the strict blockade ought to persuade anyone who accepts the principle of noncombatant immunity. But in the next two sections I will show why these analogies misdescribe many forms of blockade, including the one that cut off the flow of food into Germany during the First World War. That blockade did not "strangle" Germany, as is often claimed. It was not like "firing through" a civilian crowd. What the Allied blockade did was to force the German government to choose between providing for its people and maximizing its military might. The choices it made resulted in the deaths of hundreds of thousands of its own civilians. Their fates lay in its hands. That government should therefore be assigned responsibility for the resulting loss of life. If it had made better choices, its own civilians would not have starved. ${ }^{3}$ 


\section{Hypothetical Cases}

Walzer allows sieges to be stricter than blockades because it is usually more feasible for the residents to flee one city than it is for a population to evacuate an entire country. Note, however, that the less practicable option may also be less necessary. A city's residents are likely to starve when their supplies are exhausted because it isn't usually feasible to produce enough food within the city's walls to make those who are trapped inside self-sufficient. The space is too restricted. When the food runs out, the population is at the besieger's mercy. Their lives are in the enemy's hands. If the civilians who would have left but couldn't then perish from hunger, it is the besieging force that kills them. That force stands between this population and its sustenance. The refusal to clear a path in or out murders these starvelings as surely as does the jailer who will not feed his inmates.

We would judge a naval blockade in the same way if the country has no possibility of feeding itself. Suppose its soil is limited or poor and it imports most of the food the population eats. Then the inhabitants are in the same situation as the residents of a city that is besieged. It isn't feasible for these people to feed themselves. They are at the mercy of their enemy, who murders them when they are allowed to starve. The responsibility in such cases shifts to the agent that has the effective power to decide whether these people eat or not. Whoever threatens to starve noncombatants is always in the wrong.

But consider the opposite case. Suppose the nation that is to be blockaded produces a surplus of food. Its soil might be rich or its population agrarian. The blockade will prevent this country from exporting its produce or importing weaponry, but it cannot starve the inhabitants. They are immune to this effect. Their lives are not at the enemy's mercy. In such a case the food 
blockade ought to be permissible. It threatens no lives. Noncombatants are not prevented by the blockader from eating their fill. Their immunity is fully respected.

The case is not some hypothetical fantasy. It corresponds roughly to the Union blockade of the Confederacy during the American Civil War. The northern navy tried to impose a strict blockade along the entire coastline of the southern states throughout the conflict (Smith 2011). Transports were not allowed in or out. But the four-year blockade by itself could not possibly have starved the southern population because the region was capable of being self-sufficient in food. Indeed, before the war it had exported agricultural produce. If some southerners did go hungry during the conflict, this was due more fundamentally to the strategic devastation of crops carried out by northern troops rather than to the naval blockade itself. The Confederate states were precisely the sort of territories it is always permissible to blockade. They had the ability to feed their people even when they were cut off from the rest of the world. No civilian lives were therefore put at risk.

So why bother to impose a naval blockade in a case like this? What did the federal government hope to accomplish? The main purpose of the blockade was to prevent the southern states from selling cash crops like cotton in order to buy weapons (Davis \& Engerman 2006: ch. 4). But the interdiction was useful, too, because it increased the difficulties with which the enemy government would be forced to cope. Scarce resources were drawn away from the military fight to solve problems in the rear. For example, because the southern coastal trade was disrupted by the Union blockade, more supplies had to be shipped overland. Rail transport was fastest, but the tracks had been laid before the war to carry commerce down to the coasts for export. Since the ports were now closed, the transportation grid had to be reconstructed to move supplies where they were needed within the Confederacy. But the South lacked the 
manufacturing capacity to build new railways or to repair equipment that broke down because of intensified war-time usage. More cumbersome methods of transport therefore had to be substituted, increasing costs and slowing shipments. The naval blockade, even though it could not hope to induce starvation by itself, helped tax the Confederacy's war effort and thus undercut its government. The rebellion was put under further stress. Its ability to wage war was weakened. This is always a fundamental purpose of commercial interdiction, including the interdiction of foodstuffs. Its aim isn't necessarily to starve the noncombatant population, which won't be feasible when the region is agriculturally self-sufficient. The goal, instead, is to distract the enemy or to force him to divert resources away from strictly military operations. His ability to fight is thereby reduced. The blockade can help to tip the balance in a protracted war when the two armies are more evenly matched.

The principle of noncombatant immunity is not infringed in a case of this sort, where the blockaded nation remains self-sufficient in food. But now consider a country that produced more than enough food before hostilities commenced but that suffers a loss of production due to the imposition of a blockade. Foreign supplies of fertilizer, for example, can no longer be imported, resulting in smaller harvests. The nation now produces only enough to ensure an adequate diet for each when foodstuffs are rationed evenly, but suppose the government chooses instead to adopt an inegalitarian rule of distribution. Soldiers, munitions workers and other favored groups are allowed to consume food at the prewar level, resulting in shortages for the rest of the population. If the war is prolonged, some in the least advantaged group will eventually starve and then perish. The question is to whom fault should be assigned for these civilian deaths.

There is certainly a causal connection between the blockade and the starvation that follows, for if the supply of fertilizer had not been blocked by the naval cordon then more than 
enough food would have been produced. However, the proximate cause of the starvation in this case was not the loss of the fertilizer itself but rather the government's subsequent decision to ration the supplies in an inegalitarian way. By diverting food to the favored groups, it produced starvation in the least advantaged population. The government might say defeat could not be avoided in any other way, but the blockading power should not be held responsible for these civilian deaths since the victims could have been spared if the food had been distributed according to need. That option was rejected by the blockaded state. To carry on with the war, it allowed its own people to starve. Their fates lay in its hands. It withheld the extra rations that meant survival for these innocents. In the press of war, the government consigned some of its own citizens to their doom.

Now some might think the blockader is still to blame in this case because he is trying to extort the surrender he cannot win through battle by threatening the lives of civilians. But the analysis is mistaken because the blockading power is in no position to threaten the lives of the noncombatants when it interdicts the supplies. That power does not hold a gun to their heads. It is not like the jailer who decides whether her inmates will be fed or not. The decision in this case belongs to another. There is food enough for all to survive if they will share it more equitably, but the cost of this option would be a loss of fighting force. The soldiers might fight less well without more food and fewer guns might be produced. To carry on with the war, the targeted government divides the rations unequally and in effect chooses to sacrifice some of its own people. It bears responsibility for the losses in the same way as would the general who chooses to sacrifice one unit in a rearguard action so as to save many more.

A general is permitted to sacrifice soldiers if this sacrifice is deemed militarily necessary. But when a government sacrifices its own civilians in order to continue the fight it might well be 
accused of having violated the principle of noncombatant immunity. According to the standard interpretation, that principle rules out deliberate armed attack (Steinhoff 2007: 48). If attack is defined narrowly, then neither the blockading nor the blockaded belligerent in the case we are considering here can be accused of attacking noncombatants. Civilians are not being shot to death. But they are being denied sustenance, which puts their lives at risk. And the belligerent that is risking their lives in this scenario is not the blockading power but the power that is being blockaded. It decides how the remaining food is to be distributed. It puts the favored groups before the others, shifting the risk to the least advantaged groups. But Walzer (2006: 157) himself argues that the risk should be shifted in the other direction, at least when soldiers conduct military operations near enemy civilian populations. Yet surely a belligerent's own noncombatants have an even better claim to be spared life-threatening risks that their own armed forces will not accept. Because they are civilians, they should not be sacrificed like the rearguard force that makes it possible for an army to escape destruction.

Requiring belligerents to adhere scrupulously to the norm of noncombatant immunity will often hamper their war effort. If they are obliged to feed even their useless mouths when this is feasible, their chances of prevailing in a close fight may sink. The war might be lost. "But," as Walzer (2006: 195) himself observes, "if it is always morally possible to fight, it is not always possible to do whatever is required to win." Sacrificing some fraction of your own population in order to fight on is morally equivalent to firing through a crowd or taking cover behind human shields. Only the direst of emergencies might justify the atrocity. In every other case the belligerent is duty-bound to spare the innocent, because this is feasible. What is feasible is also what is necessary, even though it may be inexpedient. The principle of noncombatant immunity has that kind of force within just-war theory. 
This is the framework I will use to assess the Allied blockade of Germany during the First World War. If the principles I have set forth are acceptable, then blame for the loss of civilian lives in this case should be assigned to the German government. The country could have been self-sufficient in food, even when blockaded, but it diverted resources away from agricultural production and then distributed the food it did produce unequally. The choices the German government made resulted in the deaths of hundreds of thousands of its own civilians. The Allied blockade should be faulted only for not being dismantled more quickly after the armistice was signed (Vincent 1985). While the hostilities continued, it was a legitimate way to exert pressure on an enemy government that would not concede defeat.

\section{The Causality of Starvation}

Walzer arrived at the conclusion that the Allies bore the blame for the deaths of German civilians during the First World War because of an assumption he made about why these people perished. The assumption is unstated and plausible but also false.

From the way he describes the episode, Walzer appears to think the blockade brought about an absolute shortage of food over a long enough period of time such that somebody was sure to die. There simply wasn't enough food to go around. But Walzer (2006: 173) says the Allies justified their blockade with the claim that they were only trying to starve enemy soldiers. There would have been enough rations for the civilian population, the apologists claimed, if the soldiers had been fed last instead of first. But the German government reversed the ethically correct order of eating, which doomed some of its civilians to starvation. They languished and died because of the government's choices, the Allies argued. It is the soldiers who should have gone without food. They were the target of the operation. 
Walzer rightly dismisses the Allied apology he describes. It isn't realistic to expect any government to shift the shortfall in food away from civilians in a time of war. The people with the guns are sure to be fed first. The Allies were being disingenuous in expecting the German military to go without eating when there wasn't enough food left to feed the whole population. The Allies would have made the same choice if they had started to run short of provisions.

Walzer's counterargument is persuasive in cases where the shortage of food is absolute. In the siege of a city, as its food stocks dwindle, we should assign fault for the civilians who starve not to the garrison that still draws a ration when the residents go hungry but to the besieging force that cuts off the flow of food and prevents the noncombatants from leaving.

The comparative study of famines, however, should lead us to doubt whether the assumption of absolute dearth that Walzer makes is necessarily valid in cases of naval blockade. As Amartya Sen (1981: 1) has remarked, "Starvation is the characteristic of some people not having enough food to eat. It is not the characteristic of there being not enough food to eat." In many cases of famine, it turns out, a sufficient supply of food existed in the country but it was not equitably distributed. Some ate their fill while others went hungry. This is especially likely to happen in authoritarian states, Sen (1999: 16) observes. They are built to withstand pressure from below. More responsive governments are forced to make different choices regarding the distribution of food. That is why famines do not occur in democratic societies, even when the harvest fails. The leadership isn't permitted to sacrifice some or to ignore their pleas for relief.

The German government during the First World War behaved like one of Sen's authoritarian states. The leadership acknowledged that the country had the capacity to feed itself, even if it was cut off from the rest of the world. But the government then made choices that caused some of its citizens to go without. It should therefore bear the blame for the resulting loss 
of life. In imposing their blockade, the Allies did no more than put the German government to the test. It failed the test of providing for its own people when it would have been feasible to do so because it cared more about winning the war than about providing for the least advantaged groups.

Before the onset of industrialization, the German states produced enough food to feed their people (Aereboe 1927: 8). But as a larger share of the population was drawn into factories and offices during the nineteenth century, it became increasingly cost effective to import food from overseas rather than grow it at home. This is a common pattern of development. On the eve of war, about one-fifth of the calories consumed by the German population was derived from imported foodstuffs (Offer 1989: 25). By the turn of the twentieth century, German strategists had come to recognize that the country was vulnerable to blockade, especially because the British Isles lay astride its sea lanes. A decade before the war broke out, military planners were making the assumption that in a future conflict the German coasts would be blockaded by the British fleet (Burchardt 1968). However, nothing was done before the war to stockpile food or to increase domestic production.

The German General Staff operated on the assumption that the country would be drawn into a two-front war against France and Russia. The naval blockade it also anticipated was called the third front. But the effect of any blockade was discounted because the planners expected the next war to end quickly (McKercher 2014: 120-21). Land forces were to be massed on the western front and would envelop the French army before Russian troops could be fully mobilized. The war would be over in a few months, long before the blockade could have any effect. The widely shared view in Germany and elsewhere was that modern wars would be brief. 
The stalemate that quickly ensued on the western front upended everyone's calculations. Now the third front began to assume decisive importance. In December 1914, German experts published a famous monograph that showed the country could feed itself without outside help if resources were husbanded (Eltzbacher 1914; Eltzbacher \& Wells 1915). The government adopted this point of view and prohibited the press from expressing the opinion that food would run short except through hoarding or needless wastage (Yaney 1994: 32). Gradually, government control was extended over the entire economy. A food dictatorship was established to ensure that starvation would be averted. Rationing was introduced on an unprecedented scale (Chambers 1939).

In theory, the country had the capacity to feed itself, even under blockade. Germany had exported potatoes and rye grain before the war (Moyer 1995: 81). The task of becoming selfsufficient was made difficult, though, because German crop yields depended on the heavy use of fertilizers, many of which were imported from the Americas (Vincent 1985: 125-26). Some domestic substitution was possible, but the military diverted most of the new synthetic nitrates to the armaments industry (Chambers 1939: 152). Agricultural production was further reduced because so many farmhands and their draft animals were conscripted into the army at the start of the war. More than half of the rural labor force was sent to the front, undercutting food production (Offer 1989: 27). In the next world war, by contrast, the Nazi government shifted workers to the countryside to ensure more food was produced (Gordon \& Dangerfield 1947: 206). This reduced the number of men available for conscription, but during the First World War a different choice was made. Food production was sacrificed to increase the country's fighting force. Bad weather also diminished crop yields during the second half of the war. 
If the country had been mobilized to produce grain instead of guns, there should have been no starvation. But then the military would have been reduced in size, making the defeat of its enemies in the east and the west all but impossible. Since the government was determined to achieve its war aims, it consistently subordinated civilian needs to military requirements (Guichard 1930: 304-5). Army rations were not reduced until later in the conflict (Vincent 1985: 131). Military procurement was always prioritized. Soldiers, peasants, and munitions workers were allotted several times as many calories each day as the other half of the population (Davis 2000: 180). Hunger, we should note, was an urban phenomenon. The rural population always had a sufficient supply of food (McKercher 2014: 125). Starvation afflicted mostly the poor in the big cities. People with money or connections got around the rules, but the least fortunate and the least valuable populations had to try to survive on a bread ration as meager as four ounces a day (Schreiner 1918: 214). The scheme of distribution was far from egalitarian. The government effectively decided that some mouths were useless. These people were forced to make do with whatever the others hadn't eaten.

The Allied blockade certainly put the German government under stress. It was compelled to divert resources to solve logistical problems in the rear that it would have preferred to devote to the offensive capacity of the military. For example, because overseas supplies were lost, expensive substitutes had to be developed (Guichard 1930: 266). Resources were therefore drawn away from weapons manufacture. The rail grid was forced to transport more food when it was already being burdened by increased military usage (Davis 2000: 23). While the sea is free, transit infrastructure is expensive to build and to maintain. By late in the war it was so deteriorated that shipments were delayed and provisions rotted before they reached their destination. 
The pressure the blockade induced eroded the solidarity of German society (Vincent 1985: 21). Its war effort therefore suffered. Discontent and lawlessness increased. Bread riots broke out. People drew the conclusion that the government was ineffective or didn't care about them. They hoarded food when possible, which produced shortages and led to wastage. Time was lost queuing for bread that could have been put to more productive use. The government was gradually overwhelmed by conflicting demands with which it could not effectively cope. It succumbed to pressure at the front and in the rear. Without the blockade, nearly every observer agrees, the Allies could not have prevailed in the war. If it had been tightened sooner, some argued, the war might have been brought to an end more quickly (Consett 1923: 268).

After the war, August Skalweit (1927) began his book about the wartime food policy of the German government with a few rough calculations that illustrated the nation's plight. In 1913, the average German consumed roughly 3000 calories a day. During the course of the war, this average fell by 1000 calories. The wartime average, however, concealed a great deal of variance. The more favored half of the population -- soldiers, farmers, munitions workers, the elite -- still consumed something like 3000 calories a day, but the other half wasted away on a ration of as little as 1000 calories. Hunger decimated this disadvantaged population. But before we blame the Allied blockade for these civilian deaths we should bear in mind two things. First, the blockade itself only accounted for a fraction of the lost calories. Another important reason why there was so much less food to go around was that the government had chosen to send many of its most experienced food producers to the front, reducing the harvests. Second, the blockade itself did not determine how the government distributed the food that remained. If the rations had been shared more evenly, starvation should have been averted. The war effort would have suffered, however, because an army marches on its stomach. The blockade confronted the 
imperial government with a stark choice: guns or grain. It tilted in the direction of waging war, thus dooming a fraction of its population to starvation and death. A different choice could have been made, and then the war would have ended sooner. But the war had been an enormous gamble for Germany from the start. The odds against it were greater than in a game of Russian roulette (Offer 1989: 351). Since the leadership lost the war despite neglecting its obligations, it is hard to see why the more decent choice would have been worse.

\section{Just and Unjust Blockades}

The justifications of the Allied blockade published during the First World War appealed to good and bad arguments indiscriminately (Low 1915; Headlam 1917; Jourdain 1918). On the one hand, the apologists maintained that the principle of noncombatant immunity had lapsed because the German citizenry was being mobilized for the war effort. Hence civilians could be starved just like the garrison of a fort because their government had transformed them into virtual combatants. On the other hand, it was pointed out that a country like Germany could not be starved even by a tight blockade unless its government cared more for producing guns for its soldiers than bread for its people.

This second justification is different from the first and it is the better argument too. It does not repudiate the principle of noncombatant immunity but rather points out that the principle binds governments in relation to their own citizens no less than it does in relation to belligerent populations. A government's first priority should be to see that its own people is fed. It should not devote so many resources to waging war that it begins to starve some fraction of its own population. Failure to provide for the least advantaged group when it would be feasible to do so is no better than treating civilians like the rearguard force that is sacrificed so an army can 
escape destruction. Perhaps such a maneuver would be forgivable in the darkest hour of a supreme emergency, but Germany never faced such an emergency during the whole course of the First World War.

The argument of this paper is that tight blockades or food blockades cannot be ruled out as a wartime measure. They do not necessarily violate the principle of noncombatant immunity, even when civilians in the targeted nation begin to starve and die. Such a result, I want to emphasize, should never be the intention of the blockading power. The aim of the operation must be to put pressure on the enemy state, to weaken its fighting force, and to compel it to come to terms. A country that has no possibility of feeding the population out of its own resources should not be cut off from external sources of food. To do so in such a case would amount to an attack upon the civilian population.

Since 2015, access to Yemeni ports has been impeded by a regional coalition of states (Almasmari 2015). In its first weeks, all ships were being turned away, regardless of cargo (Fink 2017). Such a tight blockade should be acceptable for a short period at most, because even in time of peace the country is not self-sufficient in food. In such cases, fault for the starvation that ensues must be assigned to the blockading force, because it is not feasible for the local authorities to feed their own people. Ought implies can, we say. But in this case can't implies don't -- do not interdict food if the country cannot feed itself. Where self-help isn't practicable, humanitarian relief is required. The blockade must be loosened.

But the corollary of this principle is that tight blockades become more acceptable as the ability of a nation to feed itself increases. It is an application of the self-help principle to which Walzer (2004: 87-90, 96, 98) himself appeals when he proscribes external intervention in domestic conflicts. In this paper I have argued that the expectation of self-help is justified if the 
country could feed itself out of its own produce before the war began. Where that is so, an enemy may interdict the external supply of foodstuffs. This will put the blockaded nation under pressure, to be sure, but the principle of noncombatant immunity should not be construed in such a way as to rule out every form of military pressure that results in harm being done to the noncombatant population. If harm is defined in the standard way as a setback to an agent's interests, then wars inevitably harm civilians. Every loss the country suffers is harmful to its people. But the principle of noncombatant immunity does not prohibit a belligerent from harming enemy civilians in certain ways or from putting their lives at risk (Lamb 2013: 37, 44). It does not even prohibit killing noncombatants, unless their deaths are intentional, reckless, or unnecessary (McMahan 2009: 219). This is why a blockade that results in civilian deaths should not be viewed as an atrocity, unless the country never had the ability to feed itself. Then responsibility shifts to the blockading power. It becomes the jailer who must feed his prisoners. But until the tables turn, the responsibility belongs to the government of those noncombatants. If it can feed these people, it must -- even though that will reduce its fighting force. There is no immunity from this obligation where it can be fulfilled. Grain before guns should be the rule.

Some belligerents violate this rule more egregiously than others. The German imperial government, I would say, miscalculated badly during the First World War but could not be accused of being indifferent to the plight of its most disadvantaged populations, let alone deliberately malevolent. The worst regimes repudiate the duty to feed the mouths they consider useless, even when this would be feasible. Blockaded by the enemy, they let a whole region starve -- perhaps because it is strategically unimportant or suspect in its loyalties. The enemy will naturally be blamed for the loss of life, which might be ended by lifting the blockade. But the blockading power is still not obligated to do so, it seems to me, because victory in this fight has 
become more urgent than ever. A population that is being starved by its own government is in need of humanitarian rescue, but the rescue can only be achieved by defeating the enemy's forces. Regime change is now in order, although it may not have been before. The war effort should therefore be intensified, not relaxed. The hostage population has to be freed. The perpetrator regime should not be accommodated or appeased.

Some will say the argument I have made in this paper allows food to be used as a weapon. But this familiar formulation is imprecise. In a naval blockade food isn't being used as a weapon. The weapon is dearth. Scarcity exerts the pressure. But this pressure will only become debilitating or lethal when the population cannot feed itself out of its own resources. Then we have to ask why. In the German case, I have argued, the fault lay with the victims' government. It prioritized weapons instead of food. Swords should have been beaten into plowshares, we might say. Fewer farmers should have been transformed into soldiers. The Allied blockade should not be held responsible for the starvation that ensued. A reckless and obstinate German militarism deserves the blame. ${ }^{4}$ 


\section{NOTES}

${ }^{1}$ There are minor exceptions to this rule. For example, pleasure craft, fishing boats, and hospital ships are not to be seized unless they engage in military activities. See Green (2008: 165-67).

${ }^{2}$ Walzer's criticism of strict blockades is the most important in the literature on just-theory theory, but similar objections are made by Christiansen \& Powers (1995: 107), Reagan (1996: 95, 127-28), Coates (1997: 198), and Primoratz (2007: 3). See also the criticism of comprehensive sanctions by Walsh (1995) and Gordon (1999). For two justifications of the Allied blockade that differ from mine, see Best (1980: 250-262) and Fotion \& Elfstrom (1986: 199-205).

${ }^{3}$ Offer (1989: 53) denies that the hunger in Germany during the war years should be described as starvation, let alone famine. These terms are highly contested (Devereux 1993). If we follow Sen (1981: 40), then the starvation in Germany amounted to a famine.

${ }^{4}$ The author would like to thank Claudio Katz, Nicole Pileggi, John Allen Williams, Muhammet Asil, Michael Schumacher, and Paul Olander, as well as the editor and referees of this journal, for commenting on earlier drafts of this paper. 


\section{REFERENCES}

Aereboe, Friedrich (1927) Der Einfluss des Krieges auf die landwirtschaftliche Produktion in Deutschland (Stuttgart: Deutsche Verlags-Anstalt).

Almasmari, Hakim (2015) Saudi Forces Blockade Yemen Amid Attacks, Wall Street Journal 31 March 2015: A.11.

Bell, Archibald Colquhoun (1937) A History of the Blockade of Germany and the Countries Associated with Her in the Great War, Austria-Hungary, Bulgaria, and Turkey, 19141918 (London: H. M. Stationery Office).

Best, Geoffrey (1980) Humanity in Warfare (New York: Columbia University Press).

Burchardt, Lothar (1968) Friedenswirtschaft und Kriegsvorsorge: Deutschlands wirtschaftliche Rüstungsbestrebungen vor 1914 (Boppard am Rhein: Harald Boldt Verlag).

Chambers, Frank (1939) The War behind the War, 1914-1918: A History of the Political and Civilian Fronts (New York: Harcourt, Brace and Company).

Christiansen, Drew \& Powers, Gerard (1995) Economic Sanctions and the Just-War Doctrine, in: David Cortright \& George Lopez (Eds), Economic Sanctions: Panacea or Peacebuilding in a Post-Cold War World?, pp. 97-117 (Boulder: Westview Press).

Coates, A. J. (1997) The Ethics of War (Manchester: Manchester University Press).

Consett, M. W. W. P. (1923) The Triumph of Unarmed Forces (1914-1918) (London: Williams and Norgate).

Coogan, John (1981) The End of Neutrality: The United States, Britain, and Maritime Rights 1899-1915 (Ithaca: Cornell University Press). 
Davis, Belinda (2000) Home Fires Burning: Food, Politics, and Everyday Life in World War I Berlin (Chapel Hill: University of North Carolina Press).

Davis, Lance \& Engerman, Stanley (2006) Naval Blockades in Peace and War: An Economic History since 1750 (Cambridge: Cambridge University Press).

De Lupis, Ingrid Detter (1987) The Law of War (Cambridge: Cambridge University Press).

Devereux, Stephen (1993) Theories of Famine (New York: Harvester Wheatsheaf).

Doswald-Beck, Louise (1995) San Remo Manual on International Law Applicable to Armed Conflicts at Sea (Cambridge: Cambridge University Press).

Eltzbacher, Paul (1914) Die deutsche Volksernährung und der englische Aushungerungsplan: eine Denkschrift (Braunschweig: F. Vieweg \& Sohn).

Eltzbacher, Paul \& Wells, S. Russell (1915) Germany's Food: Can It Last? (London: University of London Press).

Fink, Martin (2017) Naval Blockade and the Humanitarian Crisis in Yemen, Netherlands International Law Review 64/2, pp. 291-307.

Fotion, N. \& Elfstrom, G. (1986) Military Ethics: Guidelines for Peace and War (Boston: Routledge \& Kegan Paul).

Frostad, Magne (2018) Naval Blockade, Arctic Review on Law and Politics 9, pp. 195-225. Gordon, David \& Dangerfield, Royden (1947) The Hidden Weapon: The Story of Economic Warfare (New York: Harper \& Brothers Publishers).

Gordon, Joy (1999) Economic Sanction, Just War Doctrine, and the "Fearful Spectacle of the Civilian Dead," Cross Currents 49 (3), pp. 387-400.

Green, Leslie (2008) The Contemporary Law of Armed Conflict, $3^{\text {rd }}$ edition (Manchester: Manchester University Press). 
Guichard, Louis (1930) The Naval Blockade, 1914-1918, trans. Christopher Turner (New York: Appleton).

Hall, William (1924) A Treatise on International Law, $8^{\text {th }}$ edition (Oxford: Clarendon Press).

Hampshire, A. Cecil (1980) The Blockaders (London: William Kimber).

Headlam, J. W. (1917) The Starvation of Germany (London: Hodder and Stoughton).

Jessup, Philip (1928) American Neutrality and International Police (Boston: World Peace Foundation Pamphlets).

Jourdain, Margaret (1918) Air Raid Reprisals and Starvation by Blockade, International Journal of Ethics 28 (4), pp. 542-53.

Lamb, Antony (2013) Ethics and the Laws of War: The Moral Justification of Legal Norms (London: Routledge).

Low, A. Maurice (1915) "The Freedom of the Seas" (Washington: Columbian Print Co.).

McKercher, J. C. (2014) Economic Warfare, in: Hew Strachan (Ed), The Oxford Illustrated History of the First World War, pp. 119-133 (Oxford: Oxford University Press).

McMahan, Jeff (2009) Killing in War (Oxford: Clarendon Press).

Moyer, Laurence (1995) Victory Must Be Ours: Germany in the Great War, 1914-1918 (New York: Hippocrene Books).

Offer, Avner (1989) The First World War: An Agrarian Interpretation (Oxford: Clarendon Press).

Oppenheim, Lassa (1952) International Law: A Treatise, $7^{\text {th }}$ edition, Volume 2: Disputes, War and Neutrality (London: Longmans, Green and Company).

Osborne, Eric (2004) Britain's Economic Blockade of Germany, 1914-1919 (London: Frank Cass). 
Primoratz, Igor (2007) Introduction, in: Igor Primoratz (Ed.) Civilian Immunity in War, pp. 1-18 (Oxford: Oxford University Press).

Regan, Richard (1996) Just War: Principles and Cases (Washington: Catholic University of America Press).

Schreiner, George Abel (1918) The Iron Ration: Three Years in Warring Central Europe (New York: Harper \& Brothers Publishers).

Sen, Amartya (1981) Poverty and Famines: An Essay on Entitlement and Deprivation (Oxford: Clarendon Press).

Sen, Amartya (1999) Development as Freedom (New York: Knopf).

Siney, Marion (1957) The Allied Blockade of Germany, 1914-1916 (Ann Arbor: University of Michigan Press).

Skalweit, August (1927) Die deutsche Kriegsnährungswirtschaft (Stuttgart: Deutsche VerlagsAnstalt).

Smith, Andrew (2011) Starving the South: How the North Won the Civil War (New York: St. Martin's Press).

Steinhoff, Uwe (2007) On the Ethics of War and Terrorism (Oxford: Oxford University Press). Vincent, C. Paul (1985) The Politics of Hunger: The Allied Blockade of Germany, 1915-1919 (Athens: Ohio University Press).

Walsh, Brian (1995) The Iraqi Economic Blockade: A Moral and Legal Analysis, Peace Research 27 (1), pp. 47-67.

Walzer, Michael (2004) Just and Unjust Wars: A Moral Argument with Historical Illustrations, $4^{\text {th }}$ edition (New York: Basic Books). 
Winter, Jay \& Robert, Jean-Louis (1997) Capital Cities at War: Paris, London, Berlin 19141919 (Cambridge: Cambridge University Press).

Yaney, George (1994) The World of the Manager: Food Administration in Berlin during World War I (New York: Peter Lang). 